\title{
KOMUNIKASI INTERPERSONAL PUSTAKAWAN DAN PEMUSTAKA DI PERPUSTAKAAN UNIVERSITAS ISLAM NEGERI SUMATERA UTARA MEDAN
}

\author{
Hildayati Raudah \\ Universitas Islam Negeri Sumatera Utara, Medan, Indonesia \\ hildayatiraudah@gmail.com \\ Triana Santi \\ Universitas Islam Negeri Sumatera Utara, Medan, Indonesia \\ triana_santi@uinsu.ac.id
}

\begin{abstract}
The research objective is to analyze librarian and library interpersonal communication in UINSU Medan. This study uses the effectiveness theory of interpersonal communication from Devito (1986). This research method uses qualitative research methods with a phenomenological study approach. Research informants were 5 (five) librarians who worked in the UINSU library and 9 (nine) library users and through purposive sampling. Data collection techniques through observation, interviews, and documentation. Data analysis techniques use thematic analysis. Data triangulation was carried out to 9 (nine) students of UINSU Medan. The results showed that UINSU Medan library librarians had effective interpersonal communication found in several components, namely: 1)Verbal and Nonverbal Communication, 2) Openness, 3) Receiving Input, 4) Hospitality, 5) Empathy, 6) Support, 7) Familiarity, 8) Positive Thinking, 9)
\end{abstract}


Respect. Barriers that occur in misperceptions, lack of sensitivity, lack of information instructions in the library.

Keywords: Interpersonal Communication, Librarians, Users, UINSU, Medan.

\begin{abstract}
Abstrak
Tujuan penelitian adalah menganalisis komunikasi interpersonal perpustakaan dan pustakawan di UINSU Medan. Penelitian ini menggunakan teori efektivitas komunikasi interpersonal dari Devito (1986). Metode penelitian ini menggunakan metode penelitian kualitatif dengan pendekatan studi fenomenologis. Informan penelitian adalah 5 (lima) pustakawan yang bekerja di perpustakaan UINSU dan 9 (sembilan) pengguna perpustakaan dan melalui purposive sampling. Teknik pengumpulan data melalui observasi, wawancara, dan dokumentasi. Teknik analisis data menggunakan analisis tematik. Triangulasi data dilakukan untuk 9 (sembilan) mahasiswa UINSU Medan. Hasil penelitian menunjukkan bahwa pustakawan perpustakaan UINSU Medan memiliki komunikasi interpersonal yang efektif yang ditemukan dalam beberapa komponen, yaitu: 1) Komunikasi Verbal dan Nonverbal, 2) Keterbukaan, 3) Menerima Input, 4) Perhotelan, 5) Empati, 6) Dukungan, 7) Keakraban , 8) Berpikir Positif, 9) Menghormati. Hambatan yang terjadi pada mispersepsi, kurangnya kepekaan, kurangnya instruksi informasi di perpustakaan.
\end{abstract}

Kata Kunci: Komunikasi Antarpribadi, Pustakawan, Pengguna, UINSU, Medan.

\title{
A. Pendahuluan
}

\section{Latar Belakang}

Komunikasi interpersonal antara pustakawan dan pemustaka sangat dibutuhkan dalam pelayanan, baik itu pelayanan secara informasi, sikap dan tindakan yang dilakukan oleh 
seorang pustakawan di perpustakaan. Komunikasi interpersonal dibutuhkan suatu proses untuk mencapai tujuan komunikasi. Komunikasi interpersonal penyampaian pesan seorang pustakawan terkadang tidak sampai diterima dan tidak bisa dipahami oleh para pustakawan.

Komunikasi interpersonal pustakawan dan pemustaka di Universitas Islam Negeri Sumatera Utara (UINSU) Medan tidak berjalan dengan baik dan kurang efektif dikarenakan pustakawan kurang berkomunikasi dalam membina hubungan yang baik dengan pemustaka. Pustakawan mengalami masalah atau kendala pada saat menyampaikan informasi. Pustakawan harus membina komunikasi interpersonal yang baik, jelas dan ramah kepada pemustaka dalam memberikan pelayanan. Misalnya pada saat pemustaka melakukan transaksi peminjaman buku kepada pustakawan. Pustakawan bersikap tidak ramah dan tidak memberikan senyuman kepada pemustaka pada saat melakukan transaksi peminjaman/ pengembalian pada bagian sirkulasi. Untuk itu pemustaka merasa tidak nyaman dan kurang puas ketika pustakawan memberikan layanan. Pustakawan seharusnya diharapkan mampu untuk menyampaikan informasi secara ramah, tepat dan jelas, baik itu komunikasi secara verbal maupun non verbal.

Perpustakaan UIN Sumatera Utara memiliki 12 orang pegawai non pustakawan dan 5 orang pustakawan yang memiliki latar belakang yang berbeda. Diantaranya Manajemen, Pendidikan, kemudian Ilmu perpustakaan dan lain-lain. Dalam pelaksanaan kegiatan perpustakaan sering terjadi mis komunikasi antara pustakawan dengan pengguna perpustakaan. Hal ini disebabkan karena dalam proses dalam komunikasi interpersonal pustakawan tidak menguasai ilmu komunikasi dengan baik.

Dalam kegiatan sehari-hari manusia tidak lepas dari kegiatan komunikasi interpersonal dalam proses berinteraksi dengan orang lain, komunikasi interpersonal merupakan kegiatan paling dasar setiap manusia, tanpa adanya komunikasi interpersonal interaksi antara manusia tidak mungkin dapat terjadi. Hal ini 
mendorong setiap manusia agar mampu berkomunikasi dengan baik, oleh karenanya kemampuan berkomunikasi interpersonal adalah suatu kemampuan yang paling dasar yang harus dimiliki seorang manusia.

Komunikasi merupakan salah satu kegiatan yang sangat vital dan kompleks untuk kehidupan manusia, yang mana bisa dilihat bahwa komunikasi bisa terjadi pada tiap-tiap tingkah laku seseorang. Seseorang bisa terpengaruh oleh komunikasi yang dilakukan oleh orang lain, baik itu seseorang yang belum dikenal maupun orang yang dekat ataupun sudah dikenal. Hal tersebut komunikasi mempunyai peran yang sangat penting dalam kehidupan manusia, untuk itu kita Untuk itu komunikasi memiliki peran yang sangat vital bagi kehidupan manusia, oleh karena itu kita harus bisa berikan perhatian yang lebih pada sebuah komunikasi. ${ }^{1}$

Dalam berkomunikasi secara interpersonal ialah salah satu aspek yang vital di ketika dalam berhubungan antara seseorang dan orang lain pada ruang lingkup suatu pekerjaan mereka misalnya baik sesama antara karyawan dengan jabatan yang sama ataupun dengan jabatan yang berbeda. Dalam berkomunikasi secara interpersonal ialah komunikasi yang dilakukan antaraindividu dengan individu lainnya yang biasanya dilakukan secara tatap muka baik itu pada dalam situasi yang pribadi ataupun yang bersifat tidak pribadi. ${ }^{2}$

Seorang pustakawan dituntut agar mampu mengembangkan keahliannya dalam bidang komunikasi secara interpersonal. Komunikasi interpersonal merupakansuatu penyampaian informasi atau pesan dari seseorang kepada orang lain yang menerima pesan dengan tujuan mendapatkan pemahaman atau umpan balik, untuk meningkatkan pelayanan prima (excellent service) terhadap penggunan ditandai dengan adanya kerja sama yang sinergis antar pengguna dengan pustakawan guna memahami maksud dan

${ }^{1}$ Morissan, Teori komunikasi: individu hingga massa (Jakarta: Kencana Prenada Media Group, 2013), 1.

${ }^{2}$ Morissan, 14. 
tujuan antara keduanya. Hal inilah yang mendasari dibutuhkannya komunikasi interpersonal.

Melalui peningkatan dalam berkomunikasi secara interpersonal yang efektif pustakawan bisa tahu bagaimana memahami dan menjadi seseorang yang menyampaikan secara efektif, menerima pesan atau pendengar yang efektif, sehingga terselenggaranya pelayanan publik yang efektif, hal inilah yang mendasari dibutuhkannya komunikasi interpersonal yang baik bagi pustakawan agar dapat menjadi pustakawan profesional, sehingga mampu dalam memberikan pelayanan prima (excellent service) kepada pengguna perpustakaan dengan tercapainya pelayanan prima (excellent service) pengguna merasa puas sehingga tercapai tujuan utama dari suatu perpustakaan yaitu menyediakan pelayanan terhadap pengguna perpustakaan.

Dalam dunia pendidikan kehadiran perpustakaan merupakan hal terpenting dalam meningkatkan mutu pendidikan karna salah satu penunjang pembelajaran pada suatu pendidikan yaitu dibutuhkannya perpustakaan, di perpustakaan kita dapat menemukan berbagai informasi juga dengan berbagai format. Perpustakaan merupakan sebuah institusi yang mengelola koleksi karya tulis, karya cetak, dan/atau karya rekam secara profesional dengan sistem yang baku guna memenuhi kebutuhan pendidikan, penelitian, pelestarian, informasi, dan rekreasi para pemustaka.

Salah satu jenis perpustakaan yaitu perpustakaan perguruan tinggi. Perpustakaan perguruan tinggi merupakan salah satu jenis perpustakaan yang berada di perguruan tinggi baik berupa universitas, akademi, sekolah tinggi maupun institut. Fungsi perpustakaan perguruan tingggi selain dari fungsi edukasi, fungsi informasi, fungsi riset, juga berfungsi sebagai tempat rekreasi. Di perpustakaan tingkat kunjungan anggota perpustakaan adalah salah satu faktor berhasil atau tidaknya suatu perpustakaan dalam menjalankan fungsi perpustakaan.

Perpustakaan harus bisa menyediakan layanan kepada pengunjungnya, ketersediaan layanan pada perpustakaan dapat 
mempengaruhi tingkat kunjungan suatu perpustakaan, setiap perpustakaan juga berlomba-lomba dalam meningkatkan pelayanan terhadap anggotanya. Selain dari ketersediaan fasilitas kenyamanan yang disediakan oleh perpustakaan perpustakaan harus mampu memberikan penyediaan berbagai informasi kepada pengguna perpustakaan guna untuk memenuhi kebutuhan informasi yang dibutuhkan,

Pustakawan adalah orang yang memberikan dan melaksanakan kegiatan perpustakaan dalam usaha pemberian layanan kepada masyrakat sesuai dengan misi yang diemban oleh badan induknya berdasarkan ilmu perpustakaan, dokumentasi, dan informasi yang diperoleh dari pendidikan. ${ }^{3}$ Berdasarkan kutipan di atas dapat disimpulkan bahwa pustakawan adalah orang yang bertugas dalam sebuah perpustakaan yang ditugaskan untuk memberikan pelayanan kepada masyarakat atau pengguna perpustakaan berdasarkan ilmu yang diperoleh dari pendidikan perpustakaan, dokumentasi dan informasi.

Pustakawan adalah orang yang bertanggungjawab untuk menyediakan akses yang seluas-luasnya pada para pencari informasi, oleh karena itu, untuk meningkatkan suatu pelayanan pustakawan dituntut agar mampu berkomunikasi dengan baik kepada penguna jasa perpustakaan sebab dalam kesehariannya pustakawan sering berhadapan langsung dengan penggunan jasa perpustakan. Keahlian komunikasi interpersonal bagi pustakawan sangat diperlukan oleh pengguna jasa perpustakaan agar pustakawan mampu menafsirkan dan memahami maksud dan tujuan penggguna jasa perpustakaan, sehingga tercapai pelayanan prima (excellent service) kepada pengguna jasa perpustakaan.

Berdasarkan paparan yang dikemukakan diatas, judul penelitian ini yaitu komunikasi interpersonal pustakawan dengan pemustaka di perpustakaan Universitas Islam Negeri Sumatera Utara Medan. 1991), 8 .

${ }^{3}$ Sulistyo-Basuki, Pengantar Ilmu Perpustakaan (Jakarta: Gramedia, 


\section{Rumusan Masalah}

Adapun rumusan masalah dalam penelitian ini adalah:

a. Bagaimanakah proses komunikasi interpersonal antara Pustakawan dengan Pemustaka di perpustakaan Universitas Islam Negeri Sumatera Utara Medan?

b. Apa saja faktor penghambat komunikasi interpersonal Pustakawan dan Pemustaka di perpustakaan Universitas Islam Negeri Sumatera Utara Medan?

\section{Teori Komunikasi Interpersonal}

Menurut Deddy Mulyana,komunikasi interpersonal adalah komunikasi antara orang-orang secara tatap muka, yang memungkinkan setiap pesertanya menangkap reaksi orang lain secara langsung, baik secara verbal atau nonverbal. ${ }^{4}$ Komunikasi interpersonal ini adalah komunikasi yang hanya dua orang, seperti suami istri, dua sejawat, dua sahabat dekat, guru-murid dan sebagainya.

Menurut Devito, komunikasi interpersonal adalah penyampaian pesan oleh satu orang dan penerimaaan pesan oleh orang lain atau sekelompok kecil orang, dengan berbagai dampak dan dengan peluang untuk memberikan umpan balik segera. ${ }^{5}$

Jadi komunikasi interpersonal merupakan suatu proses penyampaian informasi atau pesan antara dua orang atau lebih misalnya antara komunikator dan komunikan maupun sebaliknya yang dalam suatu kelompok kecil baik itu secara verbal dan nonverbal dengan tujuan agar informasi yang disampaikan dapat untuk saling dipahami.

\section{Efektivitas Komunikasi Interpersoal}

Komunikasi interpersonal merupakan suatu proses komunikasi yang paling efektif karena komunikasi ini dilakukan

${ }^{4}$ Deddy Mulyana, Ilmu Komunikasi: Suatu Pengantar (Bandung: Remaja Rosdakarya, 2000), 73.

${ }^{5}$ Joseph A. Devito, The Interpersonal Communication Book (New York: Harper \& Row, 1986). 
secara tatap muka (face to face) para pelaku komunikasi dapat menyesuaikan diri baik dari segi isi pesan maupun dari segi perilaku, demi tercapainya tujuan komunikasi antara komunikan dan komunikator.

Menurut Joseph A.Devito, efektivitas Komunikasi Interpersonal dimulai dengan lima kualitas umum yang dipertimbangkan yaitu keterbukaan (openness), empati (empathy), sikap mendukung (supportiveness), sikap positif (positiveness), dan kesetaraan (equality). ${ }^{6}$

\section{a. Keterbukaan (Openness).}

Keterbukaan ialah sikap dapat menerima masukan dari orang lain, serta berkenaan menyampaikan informasi penting kepada orang lain. Kualitas keterbukaan mengacu pada sedikitnya tiga aspek dari komunikasi interpersonal yaitu:

Pertama, komunikator interpersonal yang efektif harus terbuka kepada orang yang diajak berinteraksi. Ini tidaklah berarti bahwa orang-orang harus dengan segera membukakan semua riwayat hidupnya. Memang ini mungkin menarik, tapi biasanya tidak membantu komunikasi. Sebaliknya, harus ada kesediaan untuk membuka diri mengungkapkan informasi yang biasanya disembunyikan, asalkan pengungkapan diri ini patut.

Kedua mengacu kepada kesediaan komunikator untuk bereaksi secara jujur terhadap stimulus yang datang. Orang yang diam, tidak kritis dan tidak tanggap pada umumnya merupakan peserta percakapan yang menjemukan. Kita ingin agar orang bereaksi secara terbuka terhadap apa yang kita ucapkan, dan kita berhak mengharapkan hal ini. Kita memperlihatkan keterbukaan dengan cara bereaksi secara spontan terhadap orang lain.

Ketiga menyangkut "kepemilikan perasaan dan pikiran. Terbuka dalam pengertian ini adalah mengakui bahwa perasaan dan pikiran yang kita lontarkan adalah memang milik kita dan kita bertanggungjawab atasnya. Cara terbaik untuk menyatakan

\footnotetext{
${ }^{6}$ Devito, $70-75$.
} 
tanggung jawab ini adalah dengan pesan yang menggunakan kata Saya (kata ganti orang pertama tunggal).

\section{b. Empati (empathy)}

Empati ialah kemampuan seseorang untuk merasakan kalau seandainya menjadi orang lain, dapat memahami sesuatu yang sedang dialami orang lain, dapat merasakan apa yang dirasakan orang lain, dan dapat memahami sesuatu persoalan dari sudut pandang orang lain, melalui kaca mata orang lain. Orang yang empatik mampu memahami motivasi dan pengalaman orang lain, perasaan dan sikap mereka, serta harapan dan keinginan mereka untuk masa mendatang. Kita dapat mengkomunikasikan empati baik secara verbal maupun non verbal. Secara nonverbal, kita dapat mengkomunikasikan empati dengan memperlihatkan (1) keterlibatan aktif melalui ekspresi wajah dan gerak-gerik yang sesuai; (2) konsentrasi terpusat meliputi kontak mata, postur tubuh yang penuh perhatian, dan kedekatan fisik; serta (3) sentuhan atau belaian yang sepantasnya.

\section{c. Sikap mendukung (supportiveness)}

Hubungan interpersonal yang efektif adalah hubungan di mana terdapat sikap mendukung (supportiveness). Artinya masing-masing pihak yang berkomunikasi memiliki komitmen untuk mendukung terselenggaranya interaksi secara terbuka.

\section{d. Sikap positif (positiveness)}

Sikap positif ditunjukkan dalam bentuk sikap dan perilaku. Sikap positif dapat ditunjukkan dengan berbagai macam perilaku dan sikap, antara lain:

Menghargai orang lain

c. Berfikiran positif terhadap orang lain

d. Tidak menaruh curiga secara berlebihan

e. Meyakini pentingnya orang lain

f. Memberikan pujian dan penghargaan

g. Komitmen menjalin kerjasama

h. Kesetaraan (equality) 
Dalam setiap situasi, barangkali terjadi ketidaksetaraan. Tidak pernah ada dua orang yang benar-benar setara. Terlepas dari ketidaksetaraan ini, komunikasi interpersonal akan lebih efektif bila suasananya setara Artinya, pengakuan bahwa kedua belah pihak memiliki kepentingan, kedua belah pihak sama-sama bernilai dan berharga, dan saling memerlukan.

Peneliti menggunakan teori ini sebagai acuan dalam melakukan penelitian komunikasi interpersonal antara pustakawan dan pemustaka di perpustakaan UINSU. Peneliti melihat apakah poin-poin dari efektifitas komunikasi tersebut muncul dalam interaksi komunikasi interpersonal antara pustakawan dan pemustaka.

\section{Metode Penelitian}

Penelitian ini menggunakan metode penelitian kualitatif dengan pendekatan studi fenomenologi dikarenakan peneliti ingin memahami fenomena-fenomena yang terjadi pada interaksi komunikasi interpersonal pustakawan dan pemustaka di UINSU. Adapun pendekatan dalam penelitian ini adalah fenomenologi dikarenakan peneliti inginmemahami seluruh suatu peristiwa secara lengkap pada gejala-gejala apa saja yang terjadi pada komunikasi interpersonal pustakawan dan pemustaka. Informan dalam penelitian ini adalah 5 orang pustakawan dan 9 orang pemustaka di perpustakaan UINSU.

Fenomenologi merupakan membuat pengalaman nyata sebagai data pokok sebuah realitas semua yang dapat anda ketahui adalah apa yang anda alami. "Fenomenologi berarti membiarkan segala sesuatu menjadi jelas sebagaimana adanya".

Teknik pengumpulan datanya adalah dengan cara observasi, wawancara mendalam dan dokumentasi. Dalam penelitian ini peneliti melakukan observasi terlebih dahulu ke perpustakaan, ruangan perpustakaan, pustakawan dan pemustaka sesuai dengan

${ }^{7}$ Stephen W. Littlejohn dan Karen A. Foss, Teori Komunikasi: Theories of Human Communication (Jakarta: Salemba Humanika, 2013), 57. 
kajian peneliti. Kemudian melakukan wawancara mendalam kepada pustakawan dan pemustaka yang ada di perpustakaan dan melakukan dokumentasi pada saat penelitian.

Analisis data dalam penelitian ini adalah menggunakan analisis tematik. Braun dan Clarke mengatakan bahwa tematik analisis adalah sebuah teknik analisis penelitian kualitatif yang dapat mengidentifikasi, menganalisa dan melaporkan adanya pola-pola yang terdapat dalam data dan menyajikannya dengan terperinci dan lengkap. ${ }^{8}$ Analisis tematik diasumsikan sebagai sebuah cara yang paling tepat digunakan dalam penelitian yang menggunakan interpretasi sebagai salah satu teknik analisis data. Alasannya adalah karena tematik analisis bersifat sistematis, dan memudahkan peneliti untuk mengasosiasikan seberapa sering munculnya tema- tema dengan keseluruhan data yang ada.

\section{B. Pembahasan}

\section{Proses Komunikasi Interpersonal Pustakawan dan Pemustaka}

Proses komunikasi interpersonal antara pustakawan dan pemustaka yang peneliti temukan adalah bahwa pustakawan menyampaikan informasi dan memberikan pelayanan melalui komunikasi secara verbal dan nonverbal. Peneliti menemukan masalah dalam proses komunikasi interpersonal yakni pustakawan mengalami kendala dalam sensitivitas dan kurang agresif atau kurang cepat tanggap dalam berkomunikasi dan melihat situasi pada pemustaka. Sensitivitas merupakan suatu kepekaan seseorang dalam melihat keadaan dan situasi yang dilihatnya. Sensitivitas atau kepekaan sangat dibutuhkan pustakawan ketika berhadapan dengan pemustaka dalam memberikan pelayanan dan informasi. Proses komunikasi interpersonal antara pustakawan dan pemustaka terjadi karena adanya pelayanan dan penyampaian informasi secara verbal dan nonverbal kepada pemustaka dikarenakan faktor kebutuhan seorang pemustaka dalam mencari informasi yang ada di

${ }^{8}$ Virginia Braun dan Victoria Clarke, "Using thematic analysis in psychology," Qualitative Research in Psychology 3, no. 2 (1 Januari 2006): 77-101, https://doi.org/10.1191/1478088706qp063oa. 
perpustakaan baik itu pada bagian pelayanan sirkulasi, administrasi dan mencari lokasi rak buku yang dibutuhkan oleh pemustaka.

Temuan penelitian menemukan bahwa ada beberapa orang pustakawan hanya menunggu respon dari pemustaka apabila ada yang ditanyakan. Beberapa informan ada yang lebih menyukai berkomunikasi secara verbal yakni secara lisan dalam menyampaikan suatu informasi kepada pemustaka meskipun sudah ada informasi yang diberikan secara tertulis yang ditempel pada bagian pelayanan yang ada di perpustakaan. Ada juga beberapa dari informan menyampaikan informasi kepada pemustaka menggunakan komunikasi secara verbal dan ditegaskan dengan komunikasi secara nonverbal misalnya apabila ada yang bertanya tentang informasi tentang persyaratan surat bebas perpustakaan, pustakawan menjawab secara lisan tentang apa saja persyaratannya dan ditegaskan dengan gestur tangan menunjuk pada sebuah papan mading/pengumuman yang telah ditempel.

Peneliti menganalisis data menggunakan analisis tematik, peneliti mengambil inti-inti data yang penting dan mengelompokkannya ke dalam tema-tema yang ditemukan dari hasil temuan penelitian para informan. Selanjutnya peneliti melakukan variasi yakni menemukan beberapa tema yang menjadi esensi dari efektivitas komunikasi interpersonal pustakawan dan pemustaka di UINSU, tema-tema penting yang ditemukan dalam penelitian ini adalah sebagai berikut:

Dari hasil penelitian, peneliti menemukan ada beberapa esensi dari komunikasi interpersonal pustakawan dan pemustaka di UINSU yang digambarkan dalam bagan berikut ini: 


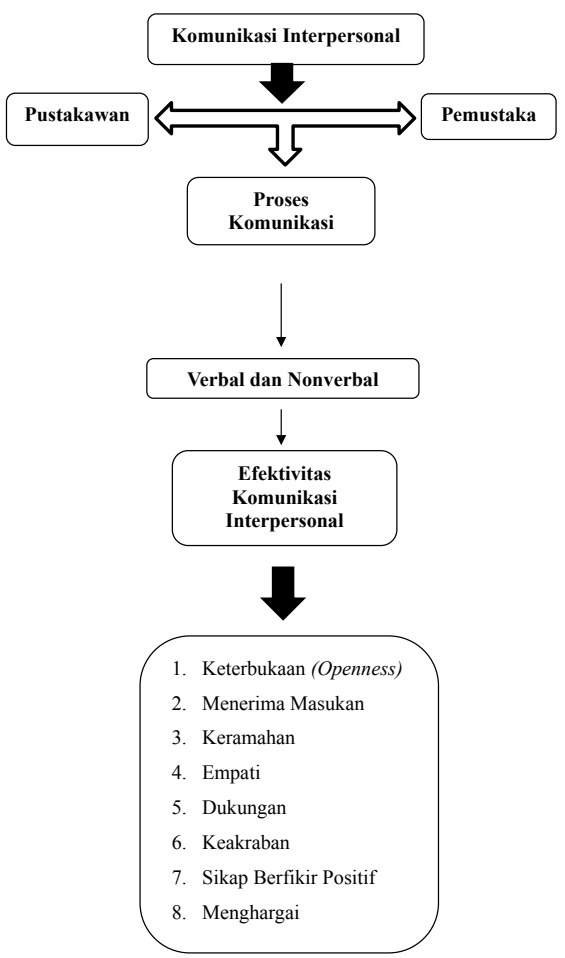

Gambar 1. Olahan Peneliti (2018) Efektifitas Komunikasi Interpersonal Pustakawan dan Pemustaka.

2. Efektifitas Komunikasi Interpersonal Pustakawan dan Pemustaka

a. Komunikasi Verbal dan Nonverbal

Pustakawan berkomunikasi menggunakan secara verbal dan nonverbal. Hasil penelitian menemukan bahwa pustakawan berkomunikasi menggunakan lambang verbal dan nonverbal untuk memberikan pelayanan yang baik kepada pemustaka.

Tabel. 1 Lambang Verbal

\begin{tabular}{|c|l|l|l|l|}
\hline \multirow{2}{*}{ No } & \multirow{2}{*}{ Nama Informan } & \multicolumn{3}{|c|}{ Lambang Verbal } \\
\cline { 3 - 5 } & Struktur pesan & \multicolumn{1}{|c|}{ Gaya pesan } & Daya tarik pesan \\
\hline 1 & Rohmawati & Tersurat & $\begin{array}{l}\text { Mudah untuk } \\
\text { dimengerti }\end{array}$ & Rasional \\
\hline 2 & Amila Ibna & Tersurat & $\begin{array}{l}\text { Terkadang sulit di } \\
\text { mengerti }\end{array}$ & Rasional \\
\hline
\end{tabular}




\begin{tabular}{|l|l|l|l|l|}
\hline 3 & Masderitawaty & Tersurat & Mudah dimengerti & Rasional \\
\hline 4 & Yuliarita & Tersurat & Mudah dimengerti & Rasional \\
\hline 5 & Wita & Tersurat & Mudah dimengerti & Rasional \\
\hline
\end{tabular}

Tabel. 2 Lambang Nonverbal

\begin{tabular}{|c|l|l|l|l|l|}
\hline No & \multicolumn{1}{|c|}{$\begin{array}{c}\text { Nama } \\
\text { Informan }\end{array}$} & \multicolumn{1}{|c|}{ Gestur } & Ekspresi & Sentuhan & Kontak Mata \\
\cline { 3 - 6 } & Rohmawati & $\begin{array}{l}\text { Sering menyentuh } \\
\text { jilbab dan banyak } \\
\text { menggerakkan } \\
\text { tangan }\end{array}$ & Ekspresif & Sering & $\begin{array}{l}\text { Selalu menatap } \\
\text { ketika } \\
\text { berkomunikasi }\end{array}$ \\
\hline 2 & Amila Ibna & $\begin{array}{l}\text { Tidak banyak } \\
\text { menggerakkan } \\
\text { tubuh }\end{array}$ & Biasa & Jarang & $\begin{array}{l}\text { Jarang } \\
\text { menatap ketika } \\
\text { berkomunikasi }\end{array}$ \\
\hline 3 & Masderitawaty & $\begin{array}{l}\text { Banyak } \\
\text { menggerakkan } \\
\text { tubuh misalnya } \\
\text { tangan }\end{array}$ & $\begin{array}{l}\text { Ekspresif } \\
\text { suka } \\
\text { tersenyum }\end{array}$ & Sering & $\begin{array}{l}\text { Selalu menatap } \\
\text { ketika } \\
\text { berkomunikasi }\end{array}$ \\
\hline 4 & Yuliarita & $\begin{array}{l}\text { Banyak } \\
\text { menggerakkan } \\
\text { tangan ketika } \\
\text { berbicara }\end{array}$ & $\begin{array}{l}\text { Biasa dan } \\
\text { berwibawa } \\
\text { menggerakkan } \\
\text { tubuh dan tangan }\end{array}$ & $\begin{array}{l}\text { Jarang } \\
\text { lemah }\end{array}$ & $\begin{array}{l}\text { Selalu menatap } \\
\text { ketika } \\
\text { berkomunikasi }\end{array}$ \\
\hline 5 & Wita & Biasa dan & sering & $\begin{array}{l}\text { Selalu menatap } \\
\text { ketika } \\
\text { berkomunikasi }\end{array}$ \\
\hline
\end{tabular}

Tabel. 3 Lambang Nonverbal Penampilan, Proksemik dan Paralinguistik

\begin{tabular}{|l|l|l|l|l|l|l|}
\hline \multirow{2}{*}{ No } & \multirow{2}{*}{$\begin{array}{c}\text { Nama } \\
\text { Informan }\end{array}$} & Penampilan & \multicolumn{2}{|c|}{ Proksemik } & \multicolumn{2}{c|}{ Paralinguistik } \\
\cline { 3 - 7 } & Pakaian & Jarak & Waktu & $\begin{array}{c}\text { Kelancaran } \\
\text { berbicara }\end{array}$ & Volume \\
\hline 1 & Rohmawati & Biasa & Sosial & Ada jeda & Lancar & Biasa \\
\hline 2 & Amila Ibna & Syar'i & Sosial & Ada jeda & Kurang & Rendah \\
\hline 3 & Masderitawaty & Menarik & Sosial & Konsisten & Lancar & Biasa \\
\hline 4 & Yuliarita & Menarik & Sosial & Konsisten & Lancar & Biasa \\
\hline 5 & Wita & Menarik & Sosial & Konsisten & Lancar & Biasa \\
\hline
\end{tabular}

1) Keterbukaan (Openness)

Hasil penelitian menemukan bahwa pustakawan sangat terbuka dan transparan dalam memberikan layanan 
dan informasi. Pustakawan suka berkomunikasi dengan para pemustaka. Pustakawan sangat terbuka ketika pemustaka menanyakan hal yang berkaitan dengan perpustakaan. Misalnya pada bagian layanan sirkulasi, pemustaka telat dalam mengembalikan buku dan menanyakan jumlah denda buku yang telah telat bertahun-tahun. Pustakawan memiliki catatan mahasiswa yang belum mengembalikan buku dan mahasiswa yang terkena denda. Di sistem perpustakaan pun juga memiliki data mahasiswa yang telat mengembalikan buku. Untuk itu pustakawan menunjukkan keterbukaannya dalam memberikan informasi. Secara verbal yakni secara lisan pustakawan mengatakan "anda terkena denda yang sudah 2 tahunan, kami memiliki catatan dan data yang ada di sistem informasi perpustakaan, jadi anda harus membayar denda tersebut" secara tertulis pun pustakawan memiliki data jumlah denda pemustaka yang telat dalam pengembalian buku.

Hasil dari penelitian ini sesuai dengan penelitian yang dilakukan oleh Hartonotentang pelayanan dan komunikasi di "Perpustakaan Kota Samarinda". perpustakaan Kota Samarinda memberikan kemudahan pemustaka untuk menambah ilmu dengan membaca dan pengelola perpustakaan kota Samarinda memberikan pelayanan yang baik. ${ }^{9}$ Hasil analisis dan penelitian dilapangan bagaimana pustakawan menerapkan komunikasi interpersonal dalam melayani pengunjung di perpustakaan kota Samarinda tentang keterbukaan (Openess) perpustakaan kota Samarinda dalam memberikan pelayanan sudah cukup baik dan pengelola perpustakaan sudah menjalankan tugasnya dengan cukup baik hanya saja masing-masing pengelola mempunyai sikap berbeda dalam memberikan pelayanan

${ }^{9}$ Mulyanto Hartono, "Penerapan Komunikasi Interpersonal Pustakawan Dalam Melayani Pengunjung Perpustakaan Kota Samarinda," eJournal Ilmu Komunikasi 4, no. 3 (2016): 548-62. 
tetapi perpustakaan terus berusaha menerapkan komunikasi yang baik terhadap pengelola maupun pemustaka.

2) Menerima Masukan

Hasil penelitian menemukan bahwa pustakawan menerima masukan dari pemustaka. Pustakawan menerima masukan dari pemustaka bisa secara langsung berdiskusi secara face to face atau tatap muka dan juga menulis saran dan komentar lewat kotak saran yang ada di perpustakaan. Komunikasi interpersonal yang terjadi antara pustakawan dan pemustaka sangat menerima kritikan dan masukan dari pemustaka agar kinerja pustakawan menjadi lebih baik dan pemustaka puas dengan pelayanan yang diberikan. Komunikasi interpersonal yang terjadi ketika pemustaka mengkritik pustakawan yang suaranya keras, judes dan dengan raut muka yang serius. Pemustaka merasa kurang puas dengan pelayanan dan cara berkomunikasi pustakawan yang keras dan judes.

3) Keramahan

Hasil penelitian menunjukkan bahwa pustakawan sangat ramah ketika berkomunikasi secara interpersonal dengan pemustaka. Pustakawan menunjukkan keramahan dengan cara tersenyum dan berbicara dengan lemah lembut kepada pemustaka. Pustakawan menunjukkan sikap ramah secara verbal dan nonverbal agar pemustaka puas dengan pelayanan yang diberikan. Oleh sebab itu pustakawan terus meningkatkan kinerjanya dengan memiliki karakter keramahan dalam komunikasi interpersonal.

4) Empati

Hasil penelitian menunjukkan bahwa pustakawan memiliki rasa empati yang baik kepada pemustaka. pustakawan berkomunikasi secara interpersonal dengan menunjukkan rasa empati. Misalnya ketika pustakawan pada bagian sirkulasi berkomunikasi dengan pemustaka tentang 
permasalahan mahasiswa yang terlambat mengembalikan buku dan harus membayar denda yang besar karena sudah telat sekitar 2 tahun. Mahasiswa yang terkena denda buku ini juga menghilangkan bukunya dan tidak sanggup membayar dan mengganti bukunya. Permasalahannya adalah pemustaka ini merasa tidak pernah meminjam buku tersebut. Namun ternyata dulu buku tersebut dipinjam oleh temannya menggunakan kartu anggota perpustakaan mahasiswa ini. Pustakawan bersikap merasakan empati dalam hal ini. Untuk itu pustakawan berusaha untuk menenangkan pemustaka agar tenang dan mencari solusi yang terbaik. Pustakawan juga merasakan hal tersebut ketika hal tersebut terjadi kapada anaknya dan tidak sanggup untuk membayar denda yang diberikan. Oleh sebab itu pustakawan melakukan komunikasi secara mendalam dan memberikan keringanan untuk pemustaka.

Penelitian ini sesuai dengan Menurut A. Anditha Sari, perpustakaan umum berbeda dengan perpustakaan sekolah, kampus, kantor, pribadi atau yang lainnya, meski berkonsep serta pengelolaannya relatif sama. Penelitian ini menyimpulkan bahwa keterampilan komunikasi interpersonal yang dilakukan oleh pustakawan ganesa telah mampu menumbuhkan empathy, supportiveness, positiveness, equality, confidence, immediacy, interaction management antara pustakawan dengan anggotanya. Sehingga anggota pun merasa puas dengan pelayanan yang diberikan oleh perpustakaan ganesa. ${ }^{10}$

5) Dukungan

Hasil penelitian menunjukkan bahwa pustakawan mendapat dukungan penuh dari kepala perpustakaan agar tujuan perpustakaan tercapai dalam memberikan pelayanan

${ }^{10}$ A.Anditha Sari, "Peran komunikasi interpersonal pustakawan dalam meningkatkan kepuasan layanan anggota perpustakaan ganesa," Jurnal IKON Prodi D3 Komunikasi Massa - Politeknik Indonusa Surakarta Vol. 1, No. 2 (Desember 2015). 
yang baik dan visi misi perpustakaan terlaksana dengan baik. Dukungan melalui kepala perpustakaan untuk pustakawan agar menambah motivasi dan semnagat para pustakawan dalam memberikan pelayanan. Kepala perpustakaan melakukan pendekatan komunikasi secara interpersonal kepada para pustakawan agar pustakawan lebih memahami maksud dan tujuan dari perpustakaan. Kepala perpustakaan juga memberikan dukungan dalam bentuk solusi apabila pustakawan mengalami kendala dalam menghadapi pemustaka ataupun terjadi permasalahan. Misalnya ketika terjadi perdebatan antara staf pada bagian administrasi dengan pemustaka. permasalahannya adalah ketika pemustaka mengurus kelengkapan berkas pembuatan surat bebas perpustakaan namun berkas mahasiswa tersebut tidak lengkap sehingga mahasiswa tersebut tetap memaksakan kehendaknya dan peran kepala perpustakaan disini sebagai mediasi untuk melakukan pendekatan dalam mengatasi masalah dengan berkomunikasi secara personal.

6) Keakraban

Hasil penelitian menunjukkan bahwa pustakawan sangat akrab dengan pemustaka dengan cara melakukan komunikasi secara intens, terbuka dan bercanda. Pustakawan melakukan hal tersebut agar komunikasi yang dilakukan lebih efektif untuk kenyamanan pemustaka. Pustakawan membuat suasana yang akrab tersebut agar perspektif pemustaka terhadap pustakawan memiliki image yang bagus dan bukan identik lagi dengan pustakawan yang pendiam, jutek dan sulit untuk tersenyum. Pustakawan melakukan komunikasi interpersonal untuk para pemustaka tidak merasa bosan, misalnya pada saat pemustaka mengurus surat bebas perpustakaan. Pustakawan harus mengecek berkasberkas tersebut apakah sudah sesuai dan lengkap. Disaat itulah pustakawan memiliki inisiatif untuk mengajak ngobrol 
dengan pemustaka agar tidak merasa bosan dan kaku untuk membuat suasana lebih nyaman.

\section{7) Sikap Berfikir Positif}

Hasil penelitian menunjukkan bahwa pustakawan selau berfikiran positif terhadap pemustaka dikarenakan untuk meningkatkan kinerja dalam memberikan pelayanan pemustaka. misalnya ketika seorang pemustaka yang masuk ke perpustakaan dan bingung ketika berada di dalam perpustakaan dikarenakan baru pertama kali masuk ke perpustakaan. Pustakawan dengan cepat tanggap dan berfikiran positif bahwa pemustaka ini sepertinya bingung karena dilihat dari lambang nonverbalnya seperti gestur dan kontak matanya. Untuk itu pustakawan langsung mengajak berkomunikasi agar pustakawan tahu apa tujuan dan maksud dari pemustaka. Pustakawan juga tahu apa yang dibutuhkan oleh pemustaka. Para pustakawan tidak ingin berfikiran negatif karena akan sulit untuk menghargai dalam memberikan pelayanan kepada pemustaka. dengan memiliki pikiran positif seorang pustakawan akan dapat lebih meningkatkan kinerja dengan cara berkomunikasi secara efektif.

\section{8) Menghargai}

Hasil penelitian menunjukkan bahwa para pustakawan memiliki sikap menghargai agar komunikasi secara interpersonal berjalan lancar dan efektif. Sikap ini ditunjukkan berkomunikasi secara verbal dan nonverbal seperti misalnya dengan menyapa dan mudah tersenyum. Menghargai pemustaka merupakan hal yang penting agar pemustaka nyaman ketika berinteraksi di lingkungan perpustakaan. Perpustakaan menjadi sangat nyaman ketika pemustaka berkunjung apabila mencari informasi yang dibutuhkannya. Dengan memiliki sikap menghargai, pemustaka merasa diperlakukan layaknya seorang raja. 
Penelitian ini sesuai dengan penelitian Tabitha, peran komunikasi interpersonal pustakawan di Perpustakaan dan Layanan Pengarsipan Propinsi Sulawesi Tenggara di Indonesia meningkatkan kenyamanan pengguna. Hasil penelitian ini menunjukkan bahwa peran komunikasi interpersonal dalam meningkatkan kenyamanan pengguna di perpustakaan dan layanan filing provinsi Sulawesi Tenggara tidak bisa dipisahkan dari model Humanistik dan model pragmatis yang menunjukkan bahwa kualitas komunikasi interpersonal yang efektif ditentukan oleh lima faktor: keterbukaan, empati, Dukungan, Positif, dan Kesetaraan. Dari kelima faktor tersebut tidak sepenuhnya berjalan dengan sempurna dalam kasus utama memiliki positif. ${ }^{11}$

\section{Hambatan komunikasi interpersonal Pustakawan dan Pemustaka}

Hasil penelitian menunjukan bahwa hambatan seorang pustakawan dalam berkomunikasi secara interpersonal adalah salah persepsi, kurangnya sensitivitas, kurangnya petunjuk informasi yang ada di perpustakaan. Ketika pemustaka memiliki persepsi sendiri terhadap perpustakaan dan kesalahan makna maksud dari seorang pustakawan kepada pemustaka. Persepsi tersebut terjadi ketika adanya konflik dalam perdebatan permasalahan pada bagian sirkulasi maupun administrasi. Pemustaka terkadang tetap memaksakan kehendaknya ketika terjadi transaksi dan komunikasi. misalnya ketika pada bagian layanan administrasi, pemustaka tetap memaksakan kehendaknya untuk bisa mengurus surat bebas perpustakaan namun syarat tersebut tidak lengkap dikarenakan tidak memiliki kartu perpustakaan. Untuk itu pustakawan sudah menjelaskan kepada pemustaka agar melengkapi syarat tersebut. Pemustaka berdalih dengan alasan yang bermacam-macam misalnya kartu perpustakaan tinggal di kampung. Pustakawan melakukan komunikasi secara persuasif namun pemustaka tetap

${ }^{11}$ Tabitha, Marsia Sumule G, dan Asrul Jaya, "Penerapan Komunikasi Interpersonal Pustakawan Dalam Meningkatkan Kenyamanan Pemustaka," Journal Ilmu KOMUNIKASI UHO Vol. 2, No. 3 (2017), http://ojs.uho.ac.id/ index.php/KOMUNIKASI/article/viewFile/2707/2025. 
memaksakan kehendaknya. Komunikasi persuasif yang dilakukan yakni dengan cara melakukan pendekatan untuk menenangkan dan menggali apa alasan sebenarnya dan menawarkan solusi yang baik untuk membujuk pemustaka tersebut. Jadi akhirnya pustakawan mengalah dan memberikan toleransi. Hambatannya disini adalah pustakawan tidak disiplin dalam menegakkan aturan dan sistem manajemen di perpustakaan. Jadi untuk itu komunikasi secara interpersonal pun tidak berjalan lancar. Dikarenakan aturan yang kurang kuat dan perlunya membangun sistem regulasi yang kuat.

Hambatan pustakawan dalam memberikan pelayanan kepada pemustaka adalah kurangnya sensitivitas. Sensitivitas sangat diperlukan ketika pustakawan kebingungan dalam mencari informasi yang ada di perpustakaan. Kepekaan inilah yang dibutuhkan dengan langsung cepat tanggap menanyakan dan membantu pemustaka dalam mencari informasi yang dibutuhkan. Disinilah komunikasi interpersonal dibutuhkan agar mendapatkan kepuasan dan kenyamanan bagi pemustaka yakni memiliki respon yang cepat, mudah memahami, bersikap empati dalam berkomunikasi.

Hambatan komunikasi interpersonal yang ada di perpustakaan adalah kurangnya informasi secara lambang verbal yakni secara tertulis seperti petunjuk informasi, gambar animasi untuk mengingatkan para pemustaka, dan pemberitahuan ketika layanan sudah tutup ataupun istirahat. Seharusnya secara tertulis perpustakaan juga menampilkan gambar animasi baik itu kata-kata, simbol ataupun gambar yang mendeskripsikan dan memberikan makna. Misalnya dengan mengingatkan dalam pengembalian buku, telat dalam mengembalikan buku, memelihara dan menjaga koleksi, baik itu sarana dan prasarana. Jadi dengan adanya komunikasi yang dilakukan menggunakan media seperti poster tulisan ataupun gambar, maka perpustakaan dapat merepresentasikan tentang aturan tata-tertib ataupun prinsipprinsip yang ada di perpustakaan. Untuk itu pemustaka jadi lebih 
mudah memahami makna dengan gambar-gambar animasi yang ditampilkan diperpustakaan.

\section{Simpulan}

Proses komunikasi interpersonal antara pustakawan dan pemustaka yang peneliti temukan adalah bahwa pustakawan menyampaikan informasi dan memberikan pelayanan melalui komunikasi secara verbal dan nonverbal. Peneliti menemukan bahwa pustakawan memiliki beberapa komponen dalam efektivitas komunikasi interpersonal yakni: 1) Komunikasi Verbal dan Nonverbal, 2) Keterbukaan (Openness), 3) Menerima Masukan, 4) Keramahan, 5) Empati, 6) Dukungan, 7) Keakraban, 8) Sikap Berfikir Positif, 9) Menghargai.Hambatan seorang pustakawan dalam komunikasi interpersonal adalah salah persepsi, kurangnya sensitivitas, kurangnya petunjuk informasi yang ada di perpustakaan. 


\section{DAFTAR PUSTAKA}

Braun, Virginia, dan Victoria Clarke. "Using thematic analysis in psychology." Qualitative Research in Psychology 3, no. 2 (1 Januari 2006): 77-101. https://doi. org/10.1191/1478088706qp063oa.

Devito, Joseph A. The Interpersonal Communication Book. New York: Harper \& Row, 1986.

Hartono, Mulyanto. "Penerapan Komunikasi Interpersonal Pustakawan Dalam Melayani Pengunjung Perpustakaan Kota Samarinda." eJournal Ilmu Komunikasi 4, no. 3 (2016): 548-62.

Littlejohn, Stephen W., dan Karen A. Foss. Teori Komunikasi: Theories of Human Communication. Jakarta: Salemba Humanika, 2013.

Morissan. Teori komunikasi: individu hingga massa. Jakarta: Kencana Prenada Media Group, 2013.

Mulyana, Deddy. Ilmu Komunikasi: Suatu Pengantar. Bandung: Remaja Rosdakarya, 2000.

Sari, A.Anditha. "Peran komunikasi interpersonal pustakawan dalam meningkatkan kepuasan layanan anggota perpustakaan ganesa." Jurnal IKON Prodi D3 Komunikasi Massa - Politeknik Indonusa Surakarta Vol. 1, No. 2 (Desember 2015).

Sulistyo-Basuki. Pengantar Ilmu Perpustakaan. Jakarta: Gramedia, 1991.

Tabitha, Marsia Sumule G, dan Asrul Jaya. "Penerapan Komunikasi Interpersonal Pustakawan Dalam Meningkatkan Kenyamanan Pemustaka." Journal Ilmu KOMUNIKASI UHO Vol. 2, No. 3 (2017). http://ojs.uho.ac.id/index.php/ KOMUNIKASI/article/viewFile/2707/2025. 
